\title{
Exploring Grade 8 Khelobedu-speaking learners' writing challenges in Sepedi Home Language in Mopani District, South Africa
}

\begin{tabular}{|c|c|}
\hline \multicolumn{2}{|c|}{$\begin{array}{l}\text { Authors: } \\
\text { Tsebo Ramothwala }{ }^{1,2} \text { (D) } \\
\text { Madikwa H. Segabutla }^{1} \text { (D) } \\
\text { Christopher Rwodzi }{ }^{1} \text { (D) } \\
\text { Dira Thokwane }{ }^{1} \text { (D) }\end{array}$} \\
\hline \multicolumn{2}{|c|}{$\begin{array}{l}\text { Affiliations: } \\
{ }^{1} \text { Department of Applied } \\
\text { Languages, Faculty of } \\
\text { Humanities, Tshwane } \\
\text { University of Technology, } \\
\text { Pretoria, South Africa }\end{array}$} \\
\hline \multicolumn{2}{|c|}{$\begin{array}{l}{ }^{2} \text { Reitumetse High School, } \\
\text { Department of Basic } \\
\text { Education, Gauteng, } \\
\text { South Africa }\end{array}$} \\
\hline \multicolumn{2}{|c|}{$\begin{array}{l}\text { Corresponding author: } \\
\text { Madikwa Segabutla, } \\
\text { segabutlamh@tut.ac.za }\end{array}$} \\
\hline \multicolumn{2}{|c|}{$\begin{array}{l}\text { Dates: } \\
\text { Received: } 26 \text { Aug. } 2020 \\
\text { Accepted: } 30 \text { Nov. } 2020 \\
\text { Published: } 12 \text { Apr. } 2021\end{array}$} \\
\hline \multicolumn{2}{|c|}{$\begin{array}{l}\text { How to cite this article: } \\
\text { Ramothwala, T., Segabutla, } \\
\text { M.H., Rwodzi, C. \& Thokwane, } \\
\text { D., 2021, 'Exploring Grade } 8 \\
\text { Khelobedu-speaking learners' } \\
\text { writing challenges in Sepedi } \\
\text { Home Language in Mopani } \\
\text { District, South Africa', } \\
\text { Literator 42(1), a1744. } \\
\text { https://doi.org/10.4102/lit. } \\
\text { v42i1.1744 }\end{array}$} \\
\hline \multicolumn{2}{|c|}{$\begin{array}{l}\text { Copyright: } \\
\text { (C) 2021. The Authors. } \\
\text { Licensee: AOSIS. This wo } \\
\text { is licensed under the } \\
\text { Creative Commons } \\
\text { Attribution License. }\end{array}$} \\
\hline \multicolumn{2}{|l|}{ Read online: } \\
\hline afista & $\begin{array}{l}\text { Scan this QR } \\
\text { code with your } \\
\text { smart phone or } \\
\text { mobile device } \\
\text { to read online. }\end{array}$ \\
\hline
\end{tabular}

In South Africa, Khelobedu-speaking leaners learn Sepedi as their 'home language' at school because Khelobedu (sometimes referred to as 'Selobedu') is classified as a dialect of Sotho. This article draws on the challenges that Grade 8 Khelobedu-speaking learners experience when writing in Sepedi Home Language. This article will encourage teachers to reflect on their teaching and support the learners to write better. The study aimed to investigate the Selobeduspeaking leaners' writing experiences in Sepedi Home Language with reference to dialectical variations, exploring the strategies learners use to adapt and making recommendations to support them. A qualitative research study was conducted at two public high schools in Mopani District. Data were collected through semi-structured interviews with four Sepedi teachers, learner group interviews with 30 learners from two high schools ( 15 per school) and 60 learner essays (30 per school). The data were analysed through content analysis and error analysis. Both the teacher interviews and learner focus group interviews revealed that the teachers used Khelobedu in the Sepedi classrooms. Moreover, teacher interviews also suggested that the learners also used Khelobedu words and pronunciation in their writing and spelt Sepedi words the way they pronounced them in Khelobedu. Further, the essays indicated that the learners struggled to write in Sepedi; they made spelling mistakes, had limited Sepedi vocabulary and struggled with conjunctive and disjunctive writing. Finally, the findings revealed that the dialectal variations between Khelobedu and Sepedi interfered with the learners' writing instead of being additive. The learners used Khelobedu words in their writing and spelt Sepedi words the way they pronounced them in Khelobedu.

Keywords: language learning; diglossic situations; dialect; language variation; Northern Sotho; Khelobedu; writing; home language.

\section{Introduction}

The aim of this article is to explore the writing experiences of Grade 8 Khelobedu-speaking learners in learning Sepedi Home Language. The focus of the article is, therefore, Khelobedu 'home language' speakers in Mopani District of Limpopo province who are learning Sepedi as home language in Grade 8. Khelobedu is a dialect of Northern Sotho (Mohale 2014; Mojela 2008), which is pronounced and sometimes written as 'Lovedu' (Parliamentary Monitoring Committee 1999), 'Selobedu' by non-speakers of the language and 'Khelobedu' by the speakers of the language. The name 'Selobedu' will be used in this study as used by other speakers and researchers in the literature reviewed. The authors of this article will refer to the language as 'Khelobedu', as used by the speakers of the language. The dialect is spoken by people in the Limpopo province, in and around the Balobedu tribe (Tzaneen and Duiwelskloof) by the people of the Rain Queen (Modjadji) (Mohale 2014). The speakers of the dialect, are predominantly found in the Mopani District of Limpopo province in areas such as Kgapane, Lenyenye, Ga-Modjadji and some other parts of Limpopo province (Tatira, Mutambara \& Chagwiza 2012). Grade 8 learners were sampled because they have been exposed to writing in Sepedi for years, therefore making them an ideal target group to talk about their writing experiences in Sepedi. Since they have already transitioned from primary school to high school for a period of a year, they have already adjusted to being in high school, thus limiting barriers to their responses.

According to the Curriculum and Assessment Policy Statement (CAPS) (Department of Basic Education 2005) and the Language in Education Policy (LiEP) (Department of Basic Education 1997) in South African school learners must learn a home language and a first additional language, chosen from the 11 official languages. As Khelobedu is not an official language in South Africa; therefore, Khelobedu-speaking learners end up learning Sepedi as their home language because Khelobedu is 
regarded as a dialect of Sepedi, which is an official language. Although it is declared in Section 29(2) of the Bill of Rights, which forms part of the South African Constitution, that everyone has the the right of all to receive education in the official language(s) of their choice in public education institutions, Khelobedu learners do not enjoy this right because Khelobedu is not recognised as an official language. According to the CAPS, which guides teaching and learning in South African public schools, the home languages offered at schools in Mopani District are Sepedi and Xitsonga (Department of Basic Education 1997). Therefore, learners who are raised in Khelobedu communities, who speak Khelobedu at home and socially are compelled to learn Sepedi as their home language in schools. To this end, Khelobedu learners are expected to use Sepedi in writing tests and examinations. However, Northern Sotho linguists such as Webb, Lepota and Ramagoshi (2004) and Mohale (2014:1) argue that although Sepedi is offered as a subject in schools, it is not spoken by learners and possibly even some teachers around Bolobedu. Nevertheless, learners are expected to learn it in the classroom as their home language. The CAPS in South Africa further stipulates that any learner who fails a home language cannot proceed to the next grade. Thus, most Khelobedu learners run the risk of repeating grades - not because they are not proficient in their home language but simply because the home language which they are compelled to learn in school is not their home language, rather a second or even a third language.

In 2014, the Grade 12 national pass rate was $75.8 \%$ and the pass rate for Mamaila Circuit, located in central Bolobedu, was $68.3 \%$. However, learners performed worse in Sepedi, especially in the Motupa Circuit (Department of Education 2005). In 2015, learner performance in Sepedi was reported as $53.71 \%$ in the Greater Tzaneen Municipality, where Maputa Circuit is located. (Observer Newspaper 2016). The learners' performance are $14.59 \%$ less than the national average, posing a serious concern in the district. The minister of Basic Education at that time period, Minister Motshekga, acknowledged that learners from primary school enter high schools without the ability to read and write in Sepedi; hence, they often find transition to the senior grades difficult (Motshekga 2009). It was against this background that the researchers decided to focus on Grade 8 learners, as they are in a transition stage from primary school into high school.

Taking into cognisance the above background, the aim of the study was to investigate Khelobedu-speaking learners' writing experiences in learning Sepedi Home Language, in Grade 8. Therefore, the focus of the investigation was, therefore, Khelobedu home language speakers, who were learning Sepedi as their home language in Grade 8. These learners were sampled to participate in the study because they are at a transition phase from primary to high school, and so they are an ideal target group to talk about their writing experiences in Sepedi. Khelobedu, in this respect, refers to a dialect of Northern Sotho (Mohale 2014; Mojela 2008), which is pronounced and sometimes written as 'Lovedu' (Parliamentary Monitoring Committee 1999). However, speakers are referred to as 'Balobedu' and are predominantly found in the Mopani District of Limpopo province in areas such as Kgapane, Lenyenye, Ga-Modjadji and some other parts of Limpopo province (Tatira et al. 2012).

Mojela (2008) argues that this dialect has not been codified, attempting to justify why it is only used for social purposes and not for academic purposes. But, despite the lack of a recognised orthography, this dialect has recently received a lot of media attention, resulting from indigenous Khelobedu music that is played across South Africa. This includes the songs Kea dowa [I am going] and Ba apa kudu [They talk too much] by Candy Mokwena and in particular the 2017 song of the year announced at Thobela FM, Ska bhora Moreki [Don't quench the buyer] by Steven Kgatla, popularly known by his stage name King Monada. The figure of speech moja sa gagwe o a iphihla in Sepedi, is said as modya'khaawe o dya a khuta in Khelobedu, which means 'you should not tell others about your fortunes', but when translated literally in English is 'he who eats his own hides himself'. The noun moja [mv3â] in Sepedi is pronounced as modya in Khelobedu and could be transcribed as [mvd3â], where the speech sound ' $j$ ' [3] in Sepedi has been changed to 'dy' [d3] in Khelobedu. Also, sa gagwe [sâ rârwE] in Sepedi, which shows possessiveness, is pronounced as khaawe [k'hââwE] in Khelobedu. This shows that the two words sa gagwe in Sepedi have been merged into one word in Khelobedu, as khaawe.

Research shows that when speakers of a dialect are expected to learn the standard form of a language, 'they are constantly corrected in their speech, often stereotyped as apathetic or unintelligent and they encounter challenges related to incorrect spelling and pronunciation' (Allsop 2010:2). Therefore, because of this background that the authors sought to investigate Khelobedu-speaking learners' experiences as they learn to write in Sepedi as a home language. The study conducted in a different study which was conducted on the same topic, by Phokungwana (2012) on reading proficiency amongst Grade 7 Khelobedu learners showed relatively low reading achievement in Sepedi. Her study further showed that Khelobedu learners achieved below their expected proficiencies in Sepedi. This suggests that they may not be ready to begin with secondary school tasks in Sepedi, hence this article.

\section{Research questions}

The research conducted sought to answer the following research questions (RQs):

RQ1: What are the Khelobedu-speaking learners' writing experiences in Sepedi Home Language?

RQ2: How do the dialectical variations affect the writing process of Khelobedu-speaking learners in writing in Sepedi Home Language?

\section{Conceptual framework}

As a starting point language learning, writing as a skill, language variation and language proficiency are explained, followed by discussions of each of these concepts. 


\section{Language learning}

Language learning, often discussed in relation to language acquisition, 'refers to the formal learning of a language in the classroom while language acquisition means acquiring the language with little or no formal training or learning' (Singhal 2012:2). Sethole (2014) maintains that language learning is a developmental process. Krashen (1988:107) sees language acquisition as a subconscious process that entails an act of internalising language, which one has been exposed to without deliberate memorisation of a word. Furthermore, language learning takes place through learning strategies, which are defined as (Scarcella \& Oxford 1992):

[S]pecific actions, behaviours, steps, or techniques, such as seeking out conversation partners, or giving oneself encouragement to tackle a difficult language task - used by students to enhance their own learning. (p. 2)

Scarcella and Oxford argue that when the learner consciously chooses strategies that fit his or her learning style and the second language (L2) task at hand, these strategies become a useful toolkit for active, conscious and purposeful self-regulation of learning. In view of this the researchers wanted to establish the strategies used by the learners to cope with their challenges.

\section{Language learning in South African schools}

The education system in South Africa prescribes, through its policies, that all Grade 8 learners learn one official language as a home language and another as first additional language at school. Sepedi (Northern Sotho), one of the official languages in South Africa, is taught in schools as a home language and as a first additional language (Department of Basic Education 2003). Sepedi is used for teaching in lower grades and learning as a subject in some Foundation Phase classes and in some Intermediate Phase classrooms. Some school textbooks are written in Sepedi, and learners are also assessed in the language (Webb et al. 2004). As already pointed out, Northern Sotho linguists, for example Mohale (2014), are of the opinion that, although Sepedi has a written orthography and is offered as a subject in schools, it is not spoken by Khelobedu-speaking learners, including some teachers around Bolobedu. Segabutla and Evans (2019) argue that it is important for teachers to be clear verbally and nonverbally in the messages that they communicate to their learners, therefore if these teachers are not proficient in Sepedi, how will they communicate their ideas in a manner that is understandable by their learners and facilitate learning? Mohale (2014) argues that Khelobedu learners are not proficient enough to carry out tasks and assessments effectively in Sepedi, thus their performance is unsatisfactorily. The Minister of Basic Education in South Africa, supported this view and points out that learners arrive in high schools unable to write and read in Sepedi (Department of Basic Education 2009). This presents a diglossic situation, in which two distinct varieties of a language are spoken within one speech community (Schiffman 2017). In a diglossic situation one variety, is regarded as a prestigious variety contrary to the other variety is regarded as colloquial, and often the low variety has no written form (Skukauskaite \& Green 2011). Each variety has its own fixed functions and using the wrong variety in a given situation would be socially inappropriate (Yule 2006). In this case, Sepedi is regarded as superior to Khelobedu. The learners use one variety, Sepedi, for learning, whilst the other variety, Khelobedu, is used for daily communication and interactions at home and socially. Khelobedu and Sepedi also have their own fixed functions. Therefore, should learners use Khelobedu in a formal context, they are likely to be penalised by the teacher.

\section{Writing as a skill}

Writing is a form of communication between people (Mekki 2012:9) which follows conventions that relate letters to words and words to sentences, and these must be well organised to have a coherent whole, called a 'text' (Bader 2007:2). Makgai (2016:1) views writing 'like a stepping stone to broaden the learners' intellect because it helps them think logically, to plan, create, synthesize information which has to be clearly understood by the reader'. The CAPS document for Grade 8 learners prescribes that learners have to learn to listen, read, speak and write in Sepedi. Grade 8 learners are assessed in terms of five sections: extended writing, common assessment tasks, literature, tests, preparatory exam, as well as final examinations. Writing is assessed continuously through tasks such as language and comprehension exercises, creative, transactional and functional writing, as well as examinations. However, Smith (2013) points out that most learners enter the classroom with different language abilities and their own cultural understanding of what is 'correct' or 'incorrect' Sepedi. The learners' own cultural understanding might prevent them from making the necessary cognitive and emotional connections for learning, or they might simply have difficulty understanding the language used by the teacher, especially if their dialect differs much from the standard language they are learning. This might affect learners' writing skills. Thamaga (2012:2) adds that learners coming from a dialectal background tend to use both standard and non-standard vocabulary when speaking and when writing essays because they are continuously exposed to language variations, which will be discussed below.

\section{Language variation}

Bock and Mheta (2014) define language as a linguistic variety that has emerged over time with a distinct identity and that has acquired particular social values and meanings. A variation (change) is always an inherent characteristic of all languages (Wardhaugh \& Fuller 2015). Schiffman (2017) adds that all aspects of language, including phonemes, morphemes, syntactic structures and meaning, are subject to variation. Mojela (2008) argues that dialects such as Khelobedu have been sidelined from the standardisation of Northern Sotho because Northern Sotho authorities regarded them as 'inferior', 'primitive' and 'corrupt' versions of the 'prestige' dialects and standard Northern Sotho. In addition, Wardhaugh and Fuller (2015) opine that one way of 
characterising certain variations is to say that speakers of a particular language sometimes speak different dialects of that language. This might be true of Khelobedu and Sepedi, as the languages are regarded as dialects of Northern Sotho, which is the standard language. This is why Kortmann (2020) argues that dialects not only differ:

$[I] n$ linguistic competence and expressive ability among the members of any language community, each speaker uses certain linguistic features which distinguish him or her from the other members of their language community. (p. 2)

Language variation (linguistic variation) can also be defined as regional, social or contextual differences in the way a language is used (Schiffman 2017). A 'social dialect', also known as a 'sociolect', refers to a variety of a language spoken by a group of people based on social characteristics other than geography, whilst a 'regional dialect' refers to a place where the dialect is spoken (Biber 2010; Siegel 2010). Siegel (2010) adds that a regional dialect is a distinct form of a language spoken in a specific geographical area; for example, Khelobedu is spoken in Bolobedu, an area in the Limpopo province, making the language a regional dialect. Northern Sotho researchers such as Van Warmelo (1935), Ziervogel (1969) and Mokgokong (1966) assert that most Northern Sotho regional dialects have been classified according to their geographical, thus they are mainly spoken in one area of Limpopo province. Although people have migrated a lot throughout the country, this classification has not changed, and Khelobedu is spoken in Bolobedu and is still regarded as a dialect of Northern Sotho. However, although Sepedi is mainly spoken in the Sekhukhune region, it functions as a home language in various provinces in South Africa because it is recognised as a standard language. Therefore, this means that Khelobedu is a regional dialect of Sepedi, which is the current debate.

Meyerhoff (2018) argues that the term 'dialect' refers to subvarieties of a single language. This means that if a speaker of one dialect understands the other, it can be concluded that they speak the same language. For instance, if one says $o$ dha booswa in Khelobedu, meaning 'he or she eats porridge' in English, or o ja bušwa in Sepulana, or o ja bogobe in Sepedi, the speakers will understand each other well without needing an interpreter. This example shows the similarities in word order between Khelobedu, Sepulana and Sepedi. Ramajela (2011), amongst other Sepedi researchers, notes that 'most' Northern Sotho dialects are mutually intelligible, and they concur within identifiable regional boundaries. Mojela (1999) also agrees that:

[S]peakers of a Khelobedu dialect will understand speakers of Sepedi because there is a high degree of mutual intelligibility between two languages, but meaning might be lost because of the differences in vocabulary. (p. 14)

However, Manamela (2006:2) found the two languages to have variations along phonemes, amongst other areas, such as / / / versus / $\mathrm{kh} /, / \mathrm{h} /$ versus $/ \mathrm{kh} /, / \mathrm{j} /$ versus / dy / and / $\mathrm{kg} /$ versus $/ \mathrm{kh} /$, with the potential to change meaning.
These examples show the variations between Khelobedu and Sepedi, which are brought about by the fact that Khelobedu uses some of its own sounds, for example /dz/ and /dy/, which do not exist in Sepedi. In this regard, the researchers sought to establish the effect of the learners' dialect on their writing in Sepedi Home Language, in an attempt to answer RQ2. Another concept that needed attention was language proficiency, which will be discussed below.

\section{Language proficiency}

Learners' ability to write relates to language proficiency, which is 'the degree of control one has over the language in question' (Hamayan \& Damico 1991). In the study conducted, this relates to the learners becoming competent academic communicators in Sepedi in an academic environment. The Department of Basic Education (2005) views language proficiency in schools as composed of listening and speaking, reading and viewing, and writing and presenting skills. Therefore, it can be inferred that learners are expected to be proficient in all the language skills in order to be successful communicators. As Brown (2000) argues, language proficiency is also about the use of language in the classroom and is more concerned with form, where 'form' refers to the surface features of a language such as morphology and syntax.

However, the study we conducted was only limited to exploring learner proficiency in one language skill, writing, which is pivotal and foundational as far as language proficiency is concerned, especially in high schools. This is informed by the fact that most of the assessments, particularly in Sepedi, target writing skills. Thus, learners are expected to be proficient in writing, which is a way of providing variety in classroom procedures, helps learners to consolidate their grasp of vocabulary and structure and complements the other language skills (Rahel 2013).

In this research language proficiency was investigated according to Cummins' distinction between basic interpersonal communicative skills (BICS) and cognitive academic language proficiency (CALP), which he introduced in 1979 (Street \& Hornberger 2008). The BICS refer to a speaker's fluency in a language within a conversational context, whilst CALP refers to a speaker's ability to understand and express concepts and ideas relevant to his or her success in an academic setting, orally and in writing (Street \& Hornberger 2008). The study focused on the learners' ability to express themselves academically, in writing in Sepedi. Not only are Grade 8 learners expected to listen, speak and read in Sepedi socially, but they are also expected to write accurately, academically. Wessels (2014:208) explains accuracy in writing as the ability to select relevant words, which express the meaning of the writer, to keep to grammatical rules (syntactic accuracy) and to be coherent between sentences and paragraphs (inter-sentential accuracy). 


\section{Research methods and design}

The study conducted was exploratory in nature because the authors wanted to gain detailed knowledge of the challenges Grade 8 Khelobedu-speaking learners contend with, in a naturalistic learning setting, the classroom, when learning to write in Sepedi. Thus, a case study was conducted at two high schools in the Mopane District of South Africa. The study followed a qualitative approach, and data were gathered using qualitative methods through individual interviews with the teachers, focus group interviews with the learners and an analysis of learner essays.

In terms of location, the study was conducted at two public high schools in Mopani District, of the Motupa Circuit. For the purpose of this study, the schools were named PHS1 and PHS2. Both schools are in two villages in Limpopo province, in the Greater Tzaneen Municipality. The two schools were chosen as research sites because the home language spoken and the predominant language of communication in the area is Khelobedu, and the learners speak Khelobedu as their home language. This reduces the number of variables that could be in the study. Furthermore, the learners get limited exposure to Sepedi in the classroom, on Thobela FM, the provincial radio station and on some television channels, for those who can afford them. Because the schools are in rural areas, the language of communication is Khelobedu. Another reason for choosing these schools was the convenience in gathering data because the schools are near each other, which was a cost-cutting measure. In both schools Khelobedu-speaking learners are expected to learn Sepedi as a home language.

The population of the study is Grade 8 learners who speak Khelobedu as their home language but learn Sepedi as home language at school and teachers who teach Sepedi as home language in Grade 8, South African public high schools. The participants were selected through purposeful and convenient sampling methods, comprising 4 Grade 8 Sepedi teachers and 60 Grade 8 learners from two high schools in Mopani District, of the Motupa Circuit, and the learners' essays. Sixty Grade 8 learners, 30 learners per school, were purposefully sampled to write an argumentative paragraph. The learners targeted had to be Khelobedu native speakers. All in all, the learners who wrote the essays consisted of 22 boys and 38 girls aged between 14 and 15 years from both schools. From the learners who were sampled to write the essays, a further 15 learners from each school (three groups of five learners per school) were sampled, as they had to volunteer themselves for participation in the focus group interviews. Four Sepedi teachers (two per school) were sampled because it had to be the teachers who taught the Grade 8 learners already sampled, so as to triangulate the date gathered in the study. The teachers are well acquainted with the phenomenon of interest, which was the Grade 8 learners' writing experiences in Sepedi, and became the ideal group to give reliable information about the learners' writing experiences.
Three instruments were used to elicit data from the participants: Firstly, individual, once-off, semi-structured teacher interviews with four Grade 8 Sepedi Home Language teachers to establish their perceptions about their learners' writing skills. Secondly, once-off sessions of learner focus group interviews (three groups of five learners per school) were held with 30 Grade 8 Khelobedu-speaking learners, to explore the learners' experiences in writing in Sepedi. Thirdly 60 argumentative learner essays written by the learners targeted to get an idea of the errors they make in their writing. The Department of Basic Education (DBE 2009) prescribes six different types of essays that learners are to be taught and assessed from: analytical, argumentative, descriptive, discursive, expository and narrative. Learners were given a topic in Sepedi, Bohlokwa bja polelo [The importance of language], on which to write an argumentative paragraph, followed by an analysis of the essays by means of error analysis in order to identify and understand the errors learners made. The essays were marked using a rubric designed by the Department of Education in the CAPS document, which assesses three aspects of writing: content (30 marks), language (15 marks) and structure (5 marks). For the purpose of the study, only content and language were assessed, because the paragraph was too short to assess structure.

Data were also gathered through the once-off, individual, semi-structured interviews with four Grade 8 Sepedi teachers and once-off, semi-structured learner focus group interviews in Sepedi upon the requests of the participants, as this was their preferred language. The interviews were then transcribed and later translated into English to prepare them for content analysis. Data from the focus group interviews were recorded manually by one researcher, who made notes of the ideas that learners mentioned. The ideas were analysed through content analysis by grouping them according to their similarities and differences, school by school and then together. The learners' essays were first marked according to a rubric designed by the Department of Basic Education, as set out in the CAPS documents which assessed three aspects of writing: content (30 marks), language (15 marks) and structure (5 marks). A mark was then allocated to measure the learners' ability to write in Sepedi. Then, learner errors were identified and grouped manually according to the similarities and differences, consequently themes emerged from the list. The speech sounds were analysed and transcribed phonetically following the International Phonetic Alphabet (Smith 2000). The researchers had the opportunity to triangulate the data and make judgments as to whether there are challenges and whether there is dialectal interference or addition, improving the reliability of the data gathered.

Because this article emanates from the first author's master's study, ethical considerations were approved and permission to conduct the research was granted at the departmental and faculty research committee meetings in accordance with the institution's ethics clearance policy and procedures. 
Permission to gather data at the research sites was also granted by the district, the schools and the parents because the children were minors. The learners agreed to participate in the study as requested by their teachers. To ensure anonymity and confidentiality, the two schools were referred to as PHS1 and PHS2. The four teachers who were interviewed were referred to as FP1, FP2, FP3 and MF1. The learner focus groups were referred to as FGA1, FGA2, FGA3, FGB1, FGB2 and FGB3. The learner essays were grouped and labelled according to the school and the essays were allocated a number, for example Learner 1, School 1 (L1S1), which identify the script number and school.

The strength of the methods used in the study is that the case study design afforded the researchers an opportunity to conduct an in-depth study of the Grade 8 learners' writing experiences. The fact that the study was confined to Khelobeduspeaking learners could be seen as a weakness, making it difficult to generalise the findings of the study, the results can still be transferred to other contexts where learners are learning a standard language from a background. This help teachers, districts and departments of education to be aware of the learners' possible challenges and how to support them in their writing.

The implications of this study are that learners will continue to perform poorly in their writing if teachers remain oblivious of the specific factors that contribute to the learners' poor performance in their writing. If this continues, learners will lack the foundations and conventions of writing and they might exit the education system unable to write in Sepedi which will limit their chances in professions that call for writing skills such as editing, translation, writing and even language teaching. Dialectal variations are real and have the potential to influence writing, as was shown in this study. Teachers can start by ensuring that they model the language in class and insist that learners use only Sepedi in class. It is recommended that they should also reflect on their practice and support the learners by planning tasks that will specifically target the problems identified in this study, like spelling, pronunciation, conjunctive and disjunctive writing, and vowel elision and addition. Schools and districts can organise spelling bee tests and competitions to make learners aware of the different phonemes. Learners could also be given different texts written in Sepedi, for them to develop their vocabulary in Sepedi. Departments of education and districts can facilitate material development and resource distribution to make Sepedi written materials such as textbooks, study guides, videos or DVDs and dictionaries available to schools around Bolobedu, because Sepedi is not the dominant language spoken in the district (Ramothwala 2019).

\section{Findings}

The key findings of the study conducted will be presented according to the data gathered from the teacher interviews, learner focus group interviews and the learner essays. All translations are the authors' own.

\section{Learner challenges}

During the teacher interviews, when asked 'What would you say are the learners' experiences in writing Sepedi from a Khelobedu background?', the four teachers agreed that Selobedu-speaking learners find it difficult to write in Sepedi, as reflected in the following responses:

'Ka ge e le polelo ya bona ya bobedi, go ba boima go bona ka gore ba tla ba tseba medumo ya polelosemmotwana ya bona yeo e fapafapanego le ya 'the standard Sepedi' ..., gape ge ba tla sekolong se ba ruta medumo yeo e fapafapanego le ya polelo ya bona ... ba swara bothata go e bitša ka gobane medumo ya Sepedi e kwagatšwa mafelong ao a fapanego le ya Selobedu.' [Since it is their second language, it is difficult for them; they come knowing sounds of their dialect that is different to the standard Sepedi ... again we teach them sounds different to theirs, which they struggle to pronounce because Sepedi sounds are articulated in certain places different from Selobedu]. (FP1, female first participant, teacher)

'Ba foša mantšu a mantši ge ba a bitša ka gobane ba a bitša ka Selobedu ... mohlala, maada sebakeng sa maatla.' [They pronounce a lot of words incorrectly when they use their Selobedu pronunciation ... for example, maada instead of maatla]. (MF1, male first participant, teacher)

'Ba swara bothata kudu ka mopeleto, ka lebaka la gore ba na le tsebo ye nnyane ya Sepedi mola ba na le yeo e tseneletšego ya Selobedu ... mohlala: ba ngwala gwetša sebakeng sa hwetša.' [They struggle a lot with spelling because they are less exposed to Sepedi, and more exposed to Selobedu ... for example: gwetša instead of hwetša]. (FP2, female second participant, teacher)

'Ba swara bothata ka gobane ga se polelo yeo ba e šomišago ka magaeng.' [They struggle because it is not the language they use at home]. (FP3, female third participant, teacher)

In these responses, the teachers point out that the learners struggle in the language in general and that their Khelobedu pronunciation influences their spelling negatively in Sepedi writing, as summarised in Table 1. The teachers attributed these challenges to the fact that 'Sepedi is the learners' L2', '... it is not the language the learners speak at home' and that 'the dialectal variations between Sepedi and Khelobedu are wide'. These reasons support similar findings by Mokgokong (1966), the South African Consulate (2004), Webb et al. (2004) and Mojela (2008).

During the teacher interviews, they indicated that the learners use Khelobedu to explain unfamiliar concepts and to make up for their limited vocabulary in Sepedi, as expressed in the following utterances:

TABLE 1: Teachers' examples of words spelt incorrectly by learners.

\begin{tabular}{llll}
\hline Teacher & Selobedu pronunciation & Sepedi equivalent & English equivalent \\
\hline FP3 & Swanetji/swanetši & Swanetše & Should \\
FP2 & Gwetša & Hwetša & Get \\
FP2 & Khumana & Humana/hwetša & Found \\
FP1 & Sekoloni & Sekolong & At school \\
FP1 & Lapeni & Lapeng & At home \\
FP3 & Diago & Dirago & Do/does \\
\hline
\end{tabular}

Source: Ramothwala, T., 2019, 'Exploring the writing experiences of Selobedu-speaking learners in Sepedi as home language: A case study in the Mopani district', M.Tech dissertation, Department of Applied Languages, Tshwane University of Technology, Pretoria, viewed 07 January 2020, from http://tutvital.tut.ac.za:8080/vital/access/manager/ Repository/tut:4532. 
'Ee, ba šomiša tlotlontšu ya Selobedu ka gore ngwana ge a tla sekolong o tla a tseba mantšu le di dirišwa tša setšo sa bona [pause] ...' [Yes, they use Selobedu vocabulary because the learners come to school well exposed to certain aspects of culture, of their own background [pause] ...]. (FP1, female first participant, teacher)

'Ee, bana ba phela ba khe šomiša mantšu a Khelobedu ge ba khe ngwala Sepedi [pause] ...' [Yes, they use Selobedu vocabulary in their writing [pause]...]. (FP2, female second participant, teacher)

'Ee, bana ba phela ba khe šomiša mantšu a Khelobedu, nka fa mohlala [pause] o khumana ngwana a ngwadile kethune sebakeng sa Sethune ....' [Yes, they often use the Selobedu vocabulary. For instance, most learners would write Kethune instead of Sethune [the name of a village in Bolobedu] ...]. (FP3, female third participant, teacher)

'Ee, bana ba fela ba šomiša Selobedu ka lebaka la polelosemmotwana ye ba tswago go yona [pause] go ba boima ge bana ba somisa Selobedu gore barutisi bao ba sa tsebego Selobedu ba kwesise tseo ngwana a di ngwadilego [long pause] ....' [Yes, the learners do use Selobedu vocabulary because of their dialectal background. It becomes difficult for non-Selobedu native teachers to understand the learner because they do not know Selobedu [long pause] ...] (MF1, male first participant, teacher)

Interestingly enough, although the teachers requested to be interviewed in Sepedi, some of them (FP2 and FP3) responded in Khelobedu. This was confirmed by the focus group interviews, when the learners indicated that they and their teachers use Khelobedu in Sepedi classrooms to ask and answer questions, as expressed in the following statements.

Participant FGA1 mentioned that they use Selobedu in a Sepedi classroom. They noted that they use Selobedu because it is the language they speak at home and that Sepedi words are difficult for them to pronounce because they do not speak it in their surroundings.

Participant FGA3 said that they use Selobedu in a Sepedi classroom because they are accustomed to Selobedu words, as it is the language that they speak at home. They also mentioned that they are not proficient enough to use Sepedi words; hence, they use Selobedu.

Participant FGB1 remarked that they use Selobedu in the classroom during Sepedi lessons because they are not proficient enough to use Sepedi. They also disclosed that they respond to questions in Selobedu in a Sepedi classroom.

Participant FGB2 mentioned that they use Selobedu because they are not able to respond to questions in Sepedi during lessons. In addition, they mentioned that they struggle to pronounce Sepedi words, which makes them uncomfortable using Sepedi, at which point they resort to using the language they are comfortable in, Selobedu.

Five out of six groups (three from school PHS1 [FGA1, FGA2, FGA3] and two [FGB1, FGB2] from school PHS2) indicated that they use Selobedu during Sepedi lessons, whilst one group (FGB3) from school PHS2 stated that they do not use Selobedu for fear of being penalised.

From these responses, it is therefore evident that both the learners and some teachers were found to use Khelobedu in Sepedi classrooms, a practice that might lead to language delay. Thamaga (2012) warns that using a dialect during Sepedi lessons tends to confuse learners and that learners might be tempted to use the dialect as well, even during formal assessments, which is what the teachers and the students indicated is happening. One of the reasons that the learners stated for using Khelobedu in Sepedi classrooms was that they have limited vocabulary in Sepedi, which was confirmed by the findings from the learner essays, where the learners used Khelobedu vocabulary in their writing to make up for deficits in their Sepedi vocabulary. The learner essays also revealed that most learners could hardly complete a sentence without using Khelobedu words, as shown in the following examples, quoted verbatim, from the learners' essays:

'Polelo e bohlokwa kudu ka maatla. [Language is very important].' (L1S2, learner 1, school 2, gender unspecified)

'Re apa bolelo. [We speak the language].' (L15S1, learner 15, school 1, gender unspecified)

The words in bold are original to Khelobedu or used differently in Sepedi. Maatla in Sepedi means 'power or strength' but means 'very' in Khelobedu. The correct word in Sepedi is kudu. The word apa in Khelobedu means 'speak', whereas in Sepedi the correct word is bolela. The sentences should have been polelo e bohlokwa kudu kudu and re bolela polelo. The sentence construction is similar, with the differences only in vocabulary.

When the essays were graded, the results showed that learner performance in content was average for PHS1 and poor for PHS2, as reflected in Figures 1 and 2. The average and poor learner performances reflected in the figures indicate that the learners were unable to express their ideas clearly in Sepedi, suggesting a negative learner writing experience.

When the essays were analysed for language usage, which included correct sentence construction and use of Sepedi vocabulary and spelling, the results showed that the performance of the learners at both PHS1 and PHS2 remained poor, as reflected in Figures 3 and 4, respectively. The results in Figures 3 and 4 suggest that the learners are unable to use the correct Sepedi vocabulary and also struggle to write Sepedi words correctly. Unfortunately, the teachers said that when this happens, they mark the learners wrong. This supports the conclusion drawn by Khweyane (2014) on Sepulana, where he concluded that learners should be penalised for using Sepulana when writing in Sepedi. It was interesting to note that one teacher maintained that learners should not be penalised for using Khelobedu words because if they are marked wrong they might achieve poor grades. 


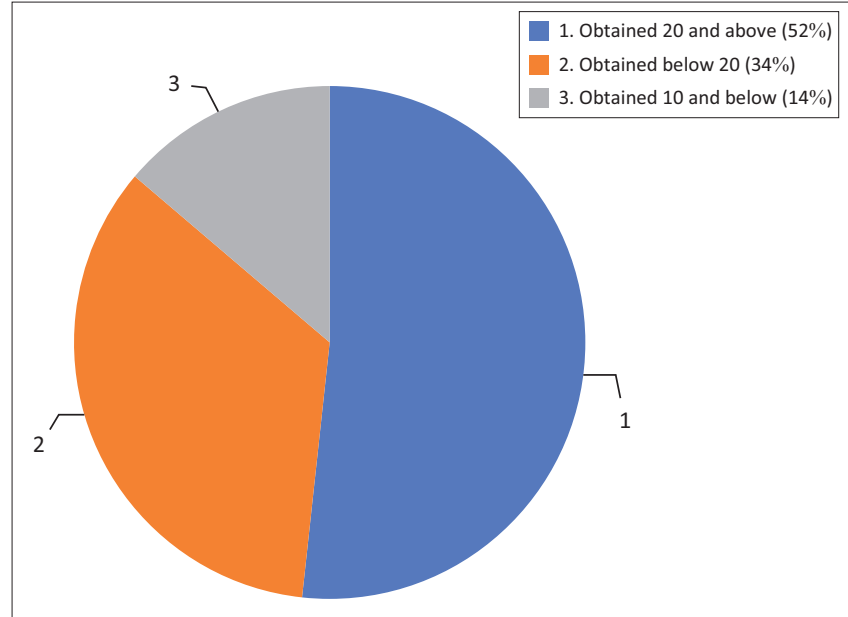

Source: Ramothwala, T., 2019, 'Exploring the writing experiences of Selobedu-speakin learners in Sepedi as home language: A case study in the Mopani district', M.Tech dissertation, Department of Applied Languages, Tshwane University of Technology, Pretoria, viewed 07 January 2020, from http://tutvital.tut.ac.za:8080/vital/access/manager/ Repository/tut:4532.

FIGURE 1: School PHS1 performance on content.

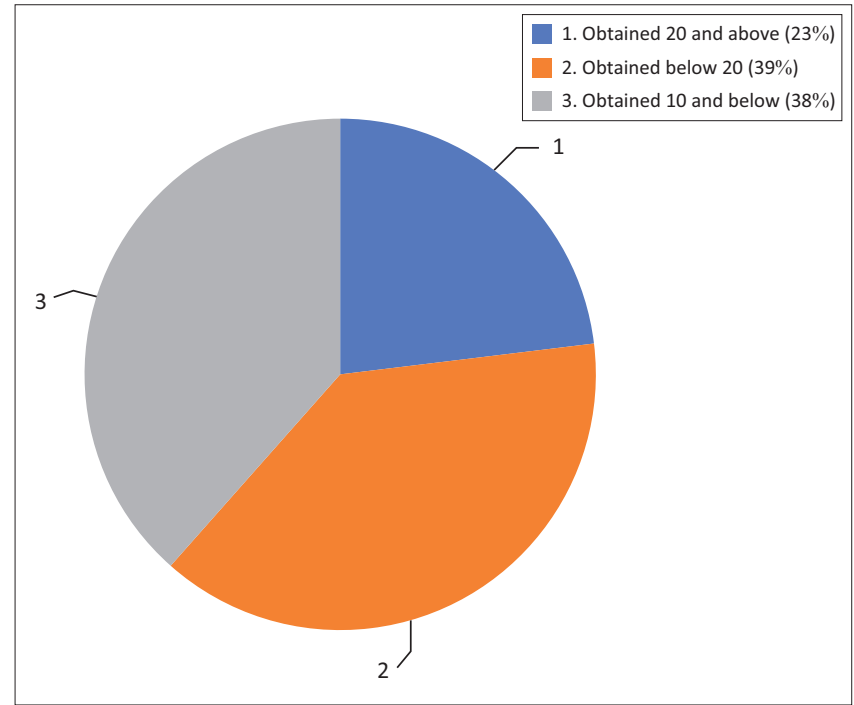

Source: Ramothwala, T., 2019, 'Exploring the writing experiences of Selobedu-speaking learners in Sepedi as home language: A case study in the Mopani district', M.Tech dissertation, Department of Applied Languages, Tshwane University of Technology, Pretoria, viewed 07 January 2020, from http://tutvital.tut.ac.za:8080/vital/access/manager/ Repository/tut:4532.

FIGURE 2: School PHS2 performance on content.

On the contrary Lu (2014), who argues that if learners are not marked wrong for incorrect vocabulary, this could cause confusion and impede the writing progress.

\section{Dialectical variations between Khelobedu and Sepedi Home Language}

Even though the focus of the study was learners' experiences in writing in Sepedi, pronunciation emerged as a variable to consider because it influenced how the learners wrote. The teachers indicated that Khelobedu learners struggle to pronounce and write Sepedi words correctly because they use Khelobedu pronunciation, which differs from Sepedi pronunciation. During the learner focus group interviews, the learners used Khelobedu pronunciation, which supports what the teachers said. Furthermore, the kind of errors

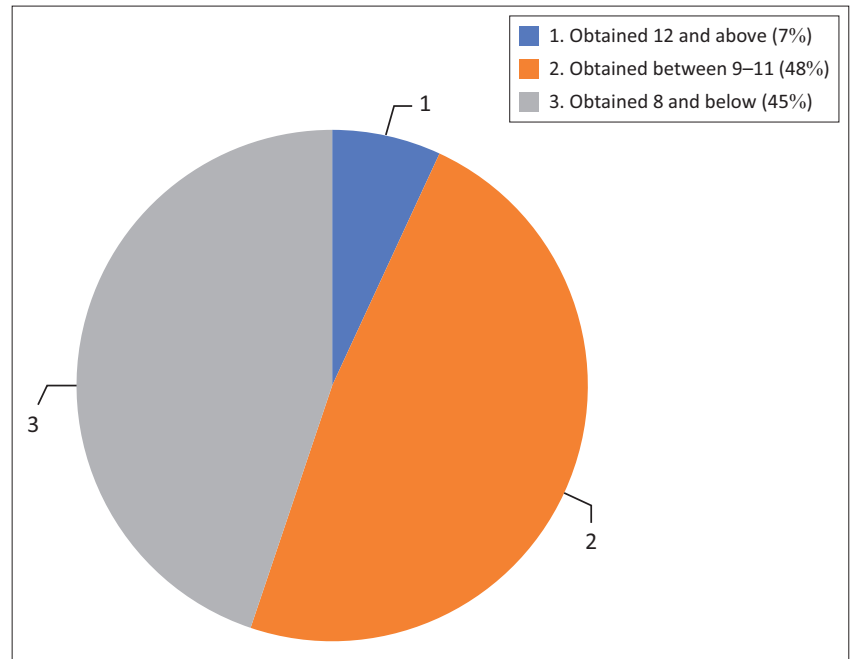

Source: Ramothwala, T., 2019, 'Exploring the writing experiences of Selobedu-speaking learners in Sepedi as home language: A case study in the Mopani district', M.Tech dissertation, Department of Applied Languages, Tshwane University of Technology, Pretoria, viewed 07 January 2020, from http://tutvital.tut.ac.za:8080/vital/access/manager/ Repository/tut:4532.

FIGURE 3: School PHS1 performance on language.

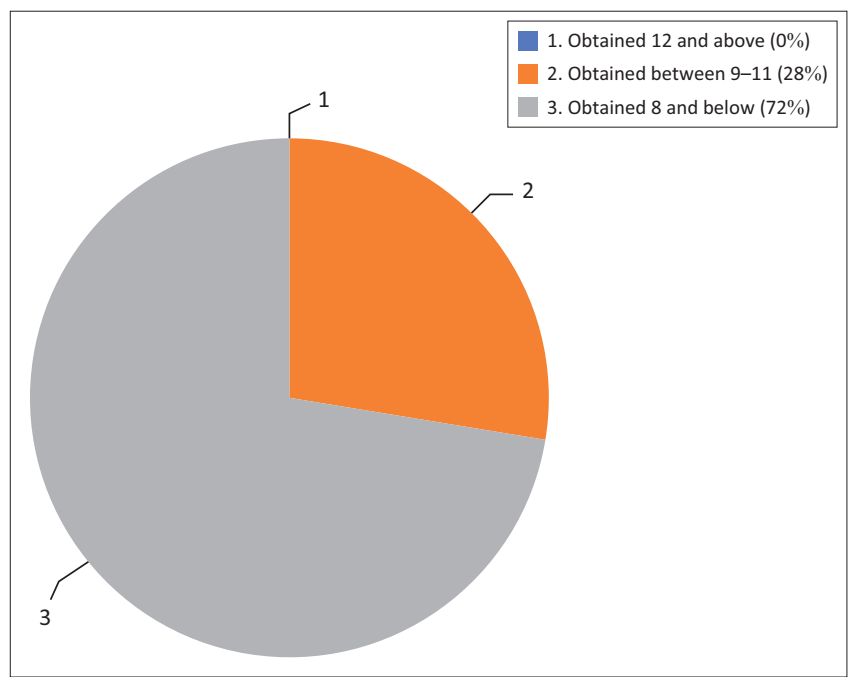

Source: Ramothwala, T., 2019, 'Exploring the writing experiences of Selobedu-speaking learners in Sepedi as home language: A case study in the Mopani district', M.Tech dissertation, Department of Applied Languages, Tshwane University of Technology, Pretoria, viewed 07 January 2020, from http://tutvital.tut.ac.za:8080/vital/access/manager/ Repository/tut:4532.

FIGURE 4: School PHS2 performance on language.

learners made in the essays suggested that they write the way they pronounce words in Khelobedu, as reflected in the following examples:

'Sekoloni [Khelobedu] instead of sekolong [Sepedi] [at school].' (L3S1, learner 3, school 1, gender unspecified; L5S1, learner 5, school 1, gender unspecified; L8S1, learner 8, school 1, gender unspecified; L10SA, learner 10, school 1, gender unspecified; L12S1, learner 12, school 1, gender unspecified; L20S1, learner 20 , school 1, gender unspecified)

'Nageni [Khelobedu] instead of nageng [Sepedi] [in the veld].' (L3S1, learner 3, school 1, gender unspecified)

Spelling is an important aspect of writing in any language. During the interviews, the Sepedi teachers reported that Khelobedu learners misspell Sepedi words because they use 
speech sounds that do not exist in Sepedi but are from their Khelobedu dialect. During the focus group interviews, the learners said that they are struggling to spell words correctly in Sepedi. In the essays, the learners wrote:

'Swanetji [Khelobedu] instead of swanetše [Sepedi] [must].' (L3S2, learner 3, school 2, gender unspecified)

In this case, the learner replaced the plosive 'tši' with the Khelobedu sound 'tji'.

Also, they wrote:

'Khonea [Khelobedu] instead of kgonega [Sepedi] [possible].' (L26S1, learner 26, school 1, gender unspecified; L27S1, learner 27, school 1, gender unspecified)

The learner replaced the standard affricative ' $\mathrm{kg}^{\prime}$ with the plosive ' $k h$ ' $[\mathrm{kb}]$. Furthermore, the learners were found to use Khelobedu speech sounds such as the locative endings '-ni' and '-ne' as in thabeni/thabene [at the mountain] instead of thabeng (Sepedi) and motseni/motsene [in the village] instead of motseng (Sepedi).

Learners were also found to confuse the vowels ' $\mathrm{e}$ ' with ' $\mathrm{i}$ ' and ' $\mathrm{u}$ ' with ' $\mathrm{o}$ ', as in the following examples:

'Gesu [Khelobedu] instead of gešo [Sepedi] [of my kind].' (L1S1, learner 1, school 1, gender unspecified; L19S1, learner 19, school 1, gender unspecified; L18S2, learner 18, school 2, gender unspecified; L22S2, learner 22, school 2, gender unspecified; L24S2, learner 24, school 2, gender unspecified)

'Bulela [Khelobedu] instead of bolela [Sepedi] [talk], yenu [Khelobedu] instead of yeno [Sepedi] [of your kind] and pulelo [Khelobedu] instead of polelo [Sepedi] [language].' (L2S1, learner 2, school 1, gender unspecified; L17S1, learner 17, school 1, gender unspecified; L7S2, learner 7, school 2, gender unspecified; L19S2, learner 19, school 2, gender unspecified)

These incorrect spellings are attributed to the Khelobedu intonation and manner of articulation, in which vowels rise at the beginning or end of words. The learners wrote these words how they are pronounced in Khelobedu, suggesting that Khelobedu learners are unable to differentiate the spoken Khelobedu from the written Sepedi words.

Learners also replaced the vowels ' $\mathrm{e}$ ' with ' $\mathrm{i}$ ' and ' $\mathrm{u}$ ', as in the following examples:

'Tsiba [Khelobedu] instead of tseba [Sepedi] [know].' (L17S1, learner 17, school 1, gender unspecified)

'Malimi [Khelobedu] instead of maleme [Sepedi] [languages].' (L8S1, learner 8, school 1, gender unspecified)

'Ibile [Khelobedu] instead of ebile [Sepedi] [it was].' (L18S1, learner 18, school 1, gender unspecified)

'Pidisana [Khelobedu] instead of phedišana [Sepedi] [harmonious living].' (L24S1, learner 24, school 1, gender unspecified)

These incorrect spellings where ' $\mathrm{e}$ ' is replaced with ' $\mathrm{i}$ ' can be attributed to Khelobedu intonation, in syllables where /e/ in
Sepedi is pronounced as /i/ in Khelobedu - another confirmation that the learners write words the way that they pronounce them in Khelobedu.

The learner essays contained errors in sentence construction, where some sentences did not make sense at all because they were poorly constructed:

'Ke ile ka go bala le tsogo [Khelobedu] instead of ke ile ka gobala letsogo [Sepedi] [I got injured on the arm].' (L14S1, learner 14, school 1, gender unspecified)

'Mo ma phelong arena [Khelobedu] instead of mo maphelong arena [Sepedi] [in our lives].' (L14S1, learner 14, school 1, gender unspecified)

These examples show that the learners separated syllables that should be combined in Sepedi sentence structure, go bala instead of gobala and le tsogo instead of letsogo.

Learners also combined words that should have been written apiece, such as:

'Polelo ya Sepedi ga segantši go kaitsiba [Khelobedu] instead of polelo ya Sepedi gase gantši o ka e tseba [Sepedi] [you may not always know the one for Sepedi].' (L17S1, learner 17, school 1, gender unspecified)

'Bathoma go tlogela go bolela polelo yeo [Khelobedu] instead of ba thoma go tlogela go bolela polelo yeo [Sepedi] [they start staying away from Sepedi].' (L17S1, learner 17, school 1, gender unspecified)

Consequently, these errors might result in the loss of meaning and cause confusion to the reader. Further, the errors in the learners' writing suggest that the Khelobedu learners battle with conjunctive and disjunctive writing.

\section{Discussion}

It is evident from the data presented that the Grade 8 learners are struggling to write in Sepedi, because it is not their L1 or home language. They appear to have limited exposure to the language, the teachers do not provide reinforcement to support them because they speak Khelobedu in class, learners spell as they speak, they have limited vocabulary in Sepedi and consequently end up using Khelobedu words in Sepedi writing. As a result, their spoken language appears to interfere with their writing instead of being additive. This supports Kroll, Barry and Vann's (1981) conclusion that the writing of all learners closely resembles 'talk written down', which is likely to incorporate many features of speech, including speech sounds of their dialects. Concluded from the learners' poor performance in their essays, is that their experience of learning to write in Sepedi from a Khelobedu background is negative.

The dialectal differences between Khelobedu and Sepedi are wide and appear to influence the learners' writing negatively. Whilst the sentence structure in Khelobedu and Sepedi is 
similar in most cases, the two languages use terminology that are not even closely related, to refer to the same thing. These differences in vocabulary have the potential to make the learners unable to express their ideas clearly in Sepedi. One can also assume that when unfamiliar Sepedi words are used in the classroom, Khelobedu-speaking learners miss the meaning of the messages given in Sepedi. Khelobedu intonation differs greatly from Sepedi intonation, as a result this influences the learners' spelling in Sepedi negatively, causing Khelobedu-speaking learners to use vowels, prelaterals, locatives and alveolars incorrectly and to overuse the ' $k$ ' sound by adding the voiceless velar plosive ' $k$ ' sound. Furthermore, the learners misspell words by confusing monophthong vowels, they use rising intonation with vowels at the ends of words, they omit diacritical marks and use the alveolar ' $s$ ' instead of the prelateral ' $s$ ', and they confuse conjunctive and disjunctive writing. Unfortunately, such errors cause them low marks and they end up performing badly in Sepedi Home Language. The errors that learners make in Sepedi writing are costly because the teachers penalise them, thus their performance is affected negatively. All these experiences are contrary to behaviourist theory, where learning will occur more frequently when followed by reinforcement, imitation and association, under controlled conditions, as pointed out by Skinner (1957:167).

\section{Conclusion}

The Khelobedu-speaking learners' writing experiences in Sepedi Home Language appears to be limited. Therefore, Grade 8 learners find writing in Sepedi challenging because of the dialectal variations between Sepedi and Khelobedu. As learners' exposure to Sepedi occurs mostly in the classroom and sometimes over the radio, teacher contribute to their limited Sepedi vocabulary, because teachers do not model Sepedi but instead speak Khelobedu during Sepedi lessons. The learners are allowed to speak Khelobedu during Sepedi lessons, leading to spelling mistakes influenced by their Khelobedu pronunciation and the construction of ungrammatical sentences. These dialectal variations between Khelobedu and Sepedi result in negative transfer and interference instead of language addition.

Given the fact that the learners' written essays were characterised by numerous grammatical errors, such as incorrect spelling, incorrect vocabulary and poor sentence construction, we recommend that teachers administer spelling tests regularly to develop learners' phonemic awareness, as it is envisaged to improve learners' writing. Furthermore, we recommend that pronunciation of Sepedi be at the centre of the lessons taught so that the learners could be assisted to be aware of basic Sepedi phonics. The teachers could also assist the learners by pronouncing words slowly and in the correct Sepedi intonation.

The success of the learners in the learning process depends much on the materials and resources at the learners' disposal (in schools), amongst other things, particularly when learning a second language. These resources will help in familiarising the learners with Sepedi writing conventions and further enrich their Sepedi vocabulary, leading to improved writing skills. Therefore, the Department of Basic Education can help to make adequate Sepedi written materials such as textbooks, study guides, videos/DVDs and dictionaries available to schools around Bolobedu, because Sepedi is not dominantly spoken in the district. Perhaps it is time that Khelobedu, like languages such as Setswana and Sesotho, that share the same sentence structure but different vocabulary, which are classified with Sepedi under the Sotho language group, be recognised as a language on its own, in the same language group as Sepedi. This could be investigated in future to address the challenges faced by Khelobedu-speaking learners in home language learning.

\section{Acknowledgements Competing interests}

The authors declare that they have no financial or personal relationships that may have inappropriately influenced them in writing this research article.

\section{Authors' contributions}

T.R. conceived the original idea, conducted the experiment and wrote the manuscript with support from M.H.S.; C.R. and D.T. contributed to the conceptualisation of the article, as well as analysis and interpretation of the data, and they critically revised, edited and approved the submission of the article.

\section{Ethical considerations}

Ethical clearance for the study was granted by the Faculty Committee for Research Ethics - Humanities of Tshwane University of Technology (reference number FCRE/APL/ STD/2017/09).

\section{Funding information}

This research received no specific grant from any funding agency in the public, commercial or not-for-profit sectors.

\section{Data availability}

The data that support the findings of this study are openly available in Tshwane University of Technology Digital Open Repository (TUTDoR) at http://tutvital.tut.ac. za:8080/vital / access / manager/Repository / tut:4532/ SOURCE1.

\section{Disclaimer}

The views and opinions expressed in this article are those of the authors and do not necessarily reflect the official policy or position of any affiliated agency of the authors. 


\section{References}

Allsop, S.A., 2010, Assisting Creole-English and non-standard dialect speaking students in learning Standard English, University of Wisconsin, River Falls, WI.

Bader, S.D. \& Abu Al Hommos, M.D., 2007, The effect of Arabic proficiency on the English writing of bilingual-Jordanian students, n.I.

Biber, D., 2010, Longman student grammar of spoken and written English, Pearson Education, n.I.

Bock, Z. \& Mheta, G., 2014, Language, society and communication: An introduction, Van Schaik Publishers, Cape Town.

Brown, H.D., 2000, Principles of language learning and teaching, 4th edn., Longman, White Plains, NY.

Department of Basic Education, 1997, Language in education policy, Government Printers, Pretoria.

Department of Basic Education, 2003, Language in education policy, Government Printers, Pretoria.

Department of Basic Education, 2005, National Curriculum Statement grades 7-9 learning programme guidelines English FAL, Government Printers, Pretoria.

Department of Basic Education, 2009, The state of education in South Africa, Government Printers, Pretoria.

Hamayan, E.V. \& Damico, J.S., 1991, Developing and using a second language, Pro Ed, Austin, TX

Khweyane, M.A., 2014, 'The influence of the dialect Sepulana on the learning of Sepedi at a Sabie Circuit, Mpumalanga Province, South Africa', Masters dissertation, School of Languages and Communication Studies, University of Limpopo, Polokwane.

Kortmann, B., 2020, 'Sociolinguistics: Regional and social varieties of English', in English linguistics, pp. 201-240, J.B. Metzler, Stuttgart. https://doi. org/10.1007/978-3-476-05678-8_8

Krashen, S.D., 1988, Second language acquisition and second language learning, Prentice-Hall International, n.l., CA.

Kroll, M., Barry, M. \& Vann, R.J., 1981, Exploring speaking and writing relationships: Connections and contracts, National Council of Teachers of English, Urbana, IL.

Lu, J., 2014, 'Language stereotypes in contemporary Taiwan: Evidence from an experimental study', Journal of East Asian Studies 14, 211-248. https://doi. org/10.1017/S1598240800008912

Makgai, M.C., 2016, 'Essay writing skills: A concern in Sepedi secondary schools in the Bronkhorstspruit circuit, Gauteng province', Masters dissertation, Department of African Languages, University of Pretoria, Pretoria, viewed 23 March 2017, from, https://repository.up.ac.za/bitstream/handle/2263/53430/Makgai_Essay_2016. pdf?sequence=1\&isAllowed=y.

Manamela, M., 2006, 'Investigation into continuous speech recognition of different dialects of Northern Sotho', Masters dissertation, School of Languages and Communication Studies, University of Limpopo, Polokwane.

Mohale, M.R., 2014, 'Khelobedu cultural evolution through oral tradition', Masters dissertation, Department of African Studies, University of South Africa, Pretoria, viewed 10 September 2016, http://uir.unisa.ac.za/bitstream/handle/10500/ $14467 /$ STUDENT\%20NO $\% 20 \% 2044542356$. pdf?sequence $=1$.

Mojela. V.M,. 1999, 'Prestige terminology and its consequences in the development of Northern Sotho vocabulary', UNISA.

Mojela, V.M., 2008, 'Standardization or stigmatization? Challenges confronting lexicography and terminography in Sesotho sa Leboa', Lexikos 18(AFRILEX-reeks/ series 18: 2008), 119-130. https://doi.org/10.4314/lex.v18i1.47247

Mokgokong, P.C., 1966, 'A dialect-geographical survey of the phonology of the Northern Sotho area', M.A. dissertation, University of South Africa.

Motshekga, M.K., 2009, Education debate: Enhancing the culture of learning and teaching in our schools for better education outcomes, Peoples Assembly, Pretoria.

Meyerhoff, M., 2018, Introducing sociolinguistics, Routledge, New York, NY.

Observer Newspaper, 2016, 'Limpopo 2015 pass rate drops by 7\% to 65,9\%', viewed 07 January 2016, from https://www.observer.co.za/limpopo-2015-pass-ratedrops-by-7-to-659/.

Parliamentary Monitoring Committee, 1999, Promotion of multilingualism in South Africa (act 10 of 1999), Government Printers, Pretoria.
Phokungwana, P.F., 2012, 'Reading comprehension strategies among biliterate Grade 7 learners in Limpopo Province, South Africa', Masters dissertation, School of Languages and Communication Studies, University of Limpopo, Polokwane, viewed 15 June 2015, http://ulspace.ul.ac.za/bitstream/handle/10386/818/ viewed 15 June 2015, http://ulspace.u.
phokungwana_pf_2012.pdf?sequence=1.

Rahel, C., 2013, Four language skills in the English language, viewed 28 June 2013 from https://rahelcynthia.wordpress.com/2013/06/28/four-skills-in-the-englishlanguage/.

Ramajela, M.C., 2011 'A case study of some social varieties of Northern Sotho and their impact on the standard variety', Masters dissertation, Department of African their impact on the standard variety', Masters dissertation, Department of African Languages, University of South Africa, Pretoria, viewed 16 June 2016, from http://
uir.unisa.ac.za/bitstream/handle/10500/4824/dissertation_ramajela_mc. uir.unisa.ac. $z a / b$
pdf?sequence $=1$.

Ramothwala, T., 2019, 'Exploring the writing experiences of Selobedu-speaking learners in Sepedi as home language: A case study in the Mopani district', M.Tech dissertation, Department of Applied Languages, Tshwane University of Technology, Pretoria, viewed 07 January 2020, from http://tutvital.tut.ac.za:8080/ vital/access/manager/Repository/tut:4532.

Scarcella, R.C. \& Oxford, R., 1992, Language learning strategies: Crucial issues of concept and classification: Applied language learning, Newbury House, MA.

Schiffman, R., 2017, Diaglossia in sociolinguistics, 16 October 2018, from https:www. thoughtco.comdiaglossia-language-varities-1690392.

Segabutla, M.H. \& Evans, R., 2019, 'Lack of lecturer clarity during instruction: Possible reason for poor throughput?', South African Journal of Higher Education 33(3), 115-131. https://doi.org/10.20853/33-3-2224

Sethole, N., 2014, The nature and extent of mother tongue interference by Sepedi on the effectiveness of learning English among information technology foundation student at Tshwane University of technology, University of Pretoria, Pretoria.

Siegel, J., 2010, Second dialect acquisition, Cambridge University, Cambridge.

Singhal, V., 2012, Defining second language acquisition, Sage, London.

Skinner, B.F., 1957, Verbal behaviour, Harvard University, Cambridge, MA.

Skukauskaite, A. \& Green, J.L., 2011, 'Review essay: On transparency, epistemologies, and positioning in writing introductory qualitative research texts', Qualitative Social Research 13(1), a23, viewed from http://nbn-resolving.de/urn:nbn:de:0114fqs1201233.

Smith, C., 2000, Handbook of the International Phonetic Association: A guide to the use of the International Phonetic Alphabet (1999), University of New Mexico, Albuquerque.

Smith, C., 2013, 'Creative writing as an important tool in second language acquisition and practice', The Journal of Literature in Language Teaching 2(2), viewed from https://www.researchgate.net/publication/263203531.

South African Consulate, 2004, Use of official languages, Government Printers, Pretoria.

Street, B.V. \& Hornberger, N., 2008, Encyclopaedia of language and education. Literacy, vol. 2, Springer, New York, NY.

Tatira, B., Mutambara, L.H.N. \& Chagwiza, C.J., 2012, 'The Balobedu cultural activities and plays pertinent to primary school mathematics learning', International Education Studies 5(1), 78-85. https://doi.org/10.5539/ies.v5n1p78

Thamaga, L.J., 2012, 'IsiNdebele influence on Sepedi learners around the Dennilton Region in the Limpopo Province', MA dissertation, University of Pretoria.

Van Warmelo, N.J., 1935, A preliminary survey of the Bantu tribes of South Africa, Government Printers, Pretoria.

Wardhaugh, R. \& Fuller, J.M., 2015, An introduction to sociolinguistics, Blackwell Publisher, Malden, MA.

Webb, V., Lepota, B. \& Ramagoshi, R., 2004, 'Using Northern Sotho as medium of instruction in vocational training', Globalisation and African languages: Risks and benefits, pp. 119-146.

Wessels, M., 2014, Practical guide to facilitating language learning, Oxford University Press, Cape Town.

Yule, G., 2006, The study of language, 3rd edn., Cambridge University Press, Cambridge.

Ziervogel, D., 1969, A handbook of the Northern Sotho language, Van Schaik, Pretoria. 